Original Article

Artigo Original

Renata Mancopes ${ }^{1}$

Bruna Franciele da Trindade Gonçalves ${ }^{2}$

Cintia Conceição Costa²

Talita Cristina Favero ${ }^{2}$

Daniela Rejane Constantino Drozdz ${ }^{2}$

Diego Fernando Dorneles Bilheri ${ }^{3}$

Stéfani Fernanda Schumacher ${ }^{4}$

Keywords

Speech, Language and Hearing Sciences

Deglutition

Deglutition Disorders

Descritores

Fonoaudiologia

Deglutição

Transtornos de Deglutição
Correspondence address:

Bruna Franciele da Trindade Gonçalves Avenida Borges de Medeiros, 25, Salgado Filho, Santa Maria (RS),

Brasil, CEP: 97040-000.

E-mail: brunna_fono@yahoo.com.br

Received: 04/22/2014

Accepted: 07/28/2014

\section{Correlation between the reason for referral, clinical, and objective assessment of the risk for dysphagia}

\author{
Correlação entre o motivo do encaminhamento, \\ avaliação clínica e objetiva do risco para disfagia
}

\begin{abstract}
Purpose: To correlate the reason for referral to speech therapy service at a university hospital with the results of clinical and objective assessment of risk for dysphagia. Methods: This is a cross-sectional, observational, retrospective analytical and quantitative study. The data were gathered from the database, and the information used was the reason for referral to speech therapy service, results of clinical assessment of the risk for dysphagia, and also from swallowing videofluoroscopy. Results: There was a mean difference between the variables of the reason for the referral, results of the clinical and objective swallowing assessments, and scale of penetration/aspiration, although the values were not statistically significant. Statistically significant correlation was observed between clinical and objective assessments and the penetration scale, with the largest occurring between the results of objective assessment and penetration scale. Conclusion: There was a correlation between clinical and objective assessments of swallowing and mean difference between the variables of the reason for the referral with their respective assessment. This shows the importance of the association between the data of patient's history and results of clinical evaluation and complementary tests, such as videofluoroscopy, for correct identification of the swallowing disorders, being important to combine the use of severity scales of penetration/aspiration for diagnosis.
\end{abstract}

\section{RESUMO}

Objetivo: Correlacionar o motivo do encaminhamento para o serviço de fonoaudiologia de um hospital universitário com os resultados da avaliação clínica e objetiva do risco para disfagia. Métodos: Trata-se de um estudo transversal, observacional, analítico de caráter retrospectivo e quantitativo. Os dados utilizados foram advindos do banco de dados, sendo utilizadas as informações do motivo do encaminhamento para o serviço de Fonoaudiologia, resultados da avaliação clínica para o risco de disfagia e também da videofluoroscopia da deglutição. Resultados: Houve diferença média entre as variáveis motivo do encaminhamento, resultados encontrados na avaliação clínica e objetiva da deglutição e a escala de penetração/aspiração, embora os valores não tenham sido estatisticamente significantes. Foi constatada correlação estatisticamente significante entre avaliação clínica, avaliação objetiva e escala de penetração, sendo que a maior delas ocorreu entre os resultados da avaliação objetiva e a escala de penetração. Conclusão: Houve correlação entre a avaliação clínica e objetiva da deglutição e diferença média entre as variáveis do motivo do encaminhamento com as respectivas avaliações. Isso demonstra a importância da associação entre os dados do histórico do paciente e os resultados da avaliação clínica e exames complementares, como a videofluoroscopia, para a identificação correta da alteração de deglutição, sendo importante ainda combinar o uso de escalas de gravidade de penetração/aspiração para estabelecer o diagnóstico.
Study carried out at the Laboratório de Disfagia, Universidade Federal de Santa Maria - UFSM - Santa Maria (RS), Brazil.

(1) Curso de Graduação em Fonoaudiologia e Programa de Pós-Graduação em Distúrbios da Comunicação Humana, Universidade Federal de Santa Maria - UFSM - Santa Maria (RS), Brazil.

(2) Universidade Federal de Santa Maria - UFSM - Santa Maria (RS), Brazil.

(3) Universidade Federal de Ciências da Saúde de Porto Alegre - UFCSPA - Porto Alegre (RS), Brazil.

(4) Curso de Fonoaudiologia, Universidade Federal de Santa Maria - UFSM - Santa Maria (RS), Brazil.

Financial support: Coordenação de Aperfeiçoamento de Pessoal de Nível Superior - CAPES.

Conflict of interests: nothing to declare. 


\section{INTRODUCTION}

Swallowing is a viral vital function, and it involves many structures that, if altered, may result in several problems for the individual ${ }^{(1)}$. The anomalies of the swallowing process have a complex and multifactorial etiology, which often makes the effective diagnosis difficult. Several publications have shown that swallowing disorders are associated with elevated rates of mortality and morbidity, a very expressive cost for rehabilitation, and best therapeutic results in cases in which a clear and precocious diagnosis was possible ${ }^{(2)}$.

It is known that any alteration that compromises the correct physiological sequence of transportation of the bolus from the mouth to the entrance of the stomach may be considered dysphagia $^{(1)}$. Many patients have complaints of choking and stasis of the food in the throat; however, the decrease of laryngeal sensitivity and coughing reflex, common in dysphagia, may disguise the condition and make patient's perception difficult.

The speech therapy assessment of swallowing is performed through clinical evaluation and a test, which studies the dynamics of swallowing and may objectively clarify specific disorders in oral and/or pharyngeal phases, such as videofluoroscopy ${ }^{(3)}$.

Videofluoroscopy is considered the gold standard for the assessment of dysphagia, as it provides a dynamic image of all swallowing phases, as well as an anatomic and physiological oropharyngeal evaluation ${ }^{(4)}$. The patients who do not have complaints must be assessed very carefully and, if necessary, submitted to objective swallowing tests, avoiding complications by silent aspirations or swallowing dysfunction itself, such as malnutrition and dehydration ${ }^{(5)}$.

The indication of this test exceeds the objective of diagnosis and contributes to the understanding of the degree of alterations found and their respective etiologies, which strengthens therapeutic planning, now based on functional imaging ${ }^{(1)}$.

Those who have complaints not always present alterations during the objective swallowing test, which may be explained both by the alteration in perception and by the fact that in the objective test, it is possible to observe swallowing only for a moment, which many a times does not correspond to the conventional feeding situation. However, the complaint of the patient must be considered and correlated to the data of clinical assessment and with the data of functional swallowing ${ }^{(5)}$.

For this reason, the objective of this study was to correlate the reason of referral to speech therapy service of a university hospital with the results of clinical and objective assessments of risk for dysphagia.

\section{METHODS}

It is a cross-sectional, observational, analytical study of retrospective and quantitative character on databases. The data used came from a database, using the information of reasons for referral to a speech therapy service, results of clinical assessment for the risk of dysphagia, and also results from swallowing videofluoroscopy of patients in speech therapy at the Ambulatório de Disfagia of the Hospital Universitário de Santa Maria, from August 2011 to December 2012.
This research was approved by the ethics committee of the Universidade Federal de Santa Maria, under the number 23081.013174/2011-46. It is noteworthy that, through the confidentiality term, researchers agreed to use the information for conducting the research provided that the confidentiality of personal identities is maintained.

The inclusion criteria adopted were to present reason for referral to speech therapy services and to have complete data on the assessments in the database. The exclusion criteria were incomplete assessment data in the database. On the basis of the inclusion and exclusion criteria, 36 subject of both gender were selected, who were divided into three age groups: adults (19-44 years), middleaged (45-64 years), and elderly (65-78 years of age), according to the Health Science Descriptors.

The reasons for referral were divided into three groups: coughing, difficulties in feeding, and poor overall condition.

The Dysphagia Risk Assessment Protocol was used to assess swallowing ${ }^{(0)}$, thus holding using the water swallowing test and the pasty food swallowing test, to determine the degree of dysphagia and its behavior conducts. The level of oral ingestion was also determined using the Functional Oral Intake Scale FOIS $^{(7)}$. For the assessment, the patient was positioned sitting down or with the head elevated to $90^{\circ}$.

Besides, a cervical auscultation was performed to detect the presence of abnormal noise before or after swallowing, verifying the time of oral transit for different consistencies, considering adequate the maximum permanence time of food in the mouth as $4 \mathrm{~s}$ and slow when the oral transit was longer than $4 \mathrm{~s}$, and, simultaneously, performing an oximetry test with a portable oximeter ${ }^{(\sigma)}$. At each change of consistency, the patient was requested to pronounce the vowel $/ \alpha /$ in maximum phonation time to detect possible alterations in voice quality, such as the presence of wet voice, which is an indication of laryngeal penetration.

The videofluoroscopy was performed by an experienced speech language therapist, accompanied by a radiologist technician and/or doctor. Initially, aspects of the patients' conditions at the time of the test regarding their overall conditions, dentition, respiratory, and feeding conditions were registered.

In the actual test, the following aspects were observed: oral phase - uptake of the bolus cake phase, lip closure, positioning of the bolus, anterior oral extraoral escape, preparation/ chewing, oral ejection, coordination between the oral and pharyngeal phases, and presence of residues in the oral cavity after swallowing. In the pharyngeal phase, the following aspects were observed: velopharyngeal closure, laryngeal penetration, tracheal aspiration, residue in pharyngeal recesses, valleculae, pharyngeal wall, and piriform recesses, in addition to asymmetry in the movement downwards descent of the bolus through the pharynx. All these aspects were observed in volumes of $5 \mathrm{~mL}, 10 \mathrm{~mL}$, and free demand sips. Up to three swallowings per volume were considered normal, and the ones exceeding this number were considered multiple.

The consistencies used in the test were liquid, nectar, honey, pudding, and solid (bread or crackers). The consistencies were prepared with barium diluted to 50\%, and the thickening followed the manufacturer's instructions. The food was prepared by the examiner moments before the test. 
After the videofluoroscopy evaluation, dysphagia was classified on the basis of the study by O'Neil et al. ${ }^{(8)}$, subdividing the result of the assessment into seven levels, namely: level I, average swallowing; level II, functional swallowing; level III, mild oropharyngeal dysphagia; level IV, mild-to-moderate oropharyngeal dysphagia; level V, moderate oropharyngeal dysphagia; level VI, moderate-to-severe oropharyngeal dysphagia; and level VII, severe oropharyngeal dysphagia.

In the case of presence of penetration and/or aspiration, the scale developed by Rosenbek et al. ${ }^{(9)}$ was used. The penetration category corresponds up to level 5 on the scale and level 6 to level 8 corresponds laryngotracheal aspiration, being:

- the contrast does not enter airway respiratory pathway;

- contrast remains goes up above the vocal folds, without residue;

- contrast remains above vocal folds, visible residues;

- contrast reaches the vocal fold, without residue;

- contrast reaches the vocal fold, visible residue. The aspiration category corresponds to the following levels, namely:

- contrast exceeds goes past the glottal level, but no residue at subglottic level;

- contrast exceeds goes past glottal level with residue at subglottic level, but the patient responds; and

- contrast exceeds goes past the glottis with residue at the subglottis, but the patient does not respond.

After data tabulation, the Statistical Package for the Social Sciences (SPSS) version 1.7, Minitab 1.6, and Excel Office 2010 were used, and an statistical analysis was performed with the use of parametric tests, adopting a significance level of 5\%. To measure the degree of relation between the clinical and objective scale and the penetration scale, we used the Pearson correlation. For the comparison of the reason for referral to the speech therapy service with the mean of the clinical and objective assessments and the penetration scales variables, we used the analysis of variance test.

\section{RESULTS}

Table 1 shows the comparison of reasons for referral to the results found in clinical and objective assessments of swallowing and the penetration/aspiration scale.

Table 2 shows the correlation of clinical assessment with the objective assessment and the penetration/aspiration scale.

\section{DISCUSSION}

Dysphagia is considered to be a symptom of different etiologies and that brings clinical complications such as malnutrition, dehydration, and aspiration ${ }^{(1-10)}$. For the proper identification of the presence of swallowing disorders, the assessment must allow the comprehension of some aspects as a reason for referral, elucidation of the cause, the capability of protecting the lower airway respiratory pathway, the aspirative risk, and the condition of the patient as for nourishing and having oral water intake in a safe way ${ }^{(1-10)}$.

Table 1 shows the comparison of the reason for referral to the results found in the clinical and objective assessments of swallowing and the penetration/aspiration scale. Literature suggests several ways of performing a swallowing assessment,
Table 1. Comparison of referral with Dysphagia Risk Assessment Protocol, videofluoroscopy, and penetration scale

\begin{tabular}{lcccc}
\hline Reason for referral & $\begin{array}{c}\text { Mean } \pm \text { SD } \\
\text { (Median) }\end{array}$ & $\begin{array}{c}\text { VC } \\
(\%)\end{array}$ & Cl & p-value \\
\hline DRAP & & & & \\
$\quad$ Coughing $(n=17)$ & $2.59 \pm 1.84(2)$ & 71 & 0.87 & \\
$\quad$ Difficulty in Feeding $(n=12)$ & $2.67 \pm 2.10(2)$ & 79 & 1.19 & 0.747 \\
$\quad$ Poor overall condition $(n=7)$ & $3.29 \pm 2.56(2)$ & 78 & 1.90 & \\
Videofluoroscopy & & & & \\
$\quad$ Coughing ( $n=17)$ & $5.18 \pm 1.88(6)$ & 36 & 0.89 & \\
$\quad$ Difficulty in Feeding $(n=12)$ & $5.00 \pm 1.71(5.5)$ & 34 & 0.97 & 0.377 \\
$\quad$ Poor overall condition $(n=7)$ & $4.00 \pm 2.16(4)$ & 54 & 1.60 & \\
Penetration scale & & & & \\
$\quad$ Coughing ( $n=17)$ & $2.00 \pm 2.15(1)$ & 108 & 1.02 & \\
$\quad$ Difficulty in Feeding $(n=12)$ & $2.67 \pm 2.67(1)$ & 100 & 1.51 & 0.154 \\
$\quad$ Poor overall condition $(n=7)$ & $4.29 \pm 3.25(3)$ & 76 & 2.41 & \\
\hline
\end{tabular}

Caption: $\mathrm{VC}=$ variation coefficient $\mathrm{Cl}=$ confidence interval; $\mathrm{DRAP}=$ Dysphagia Risk Assessment Protocol; SD = standard deviation

Table 2. Correlation of the Dysphagia Risk Assessment Protocol, videofluoroscopy, and penetration scale

\begin{tabular}{lcc}
\hline & DRAP & Videofluoroscopy \\
\hline Videofluoroscopy & & \\
Correlation & $-50.1 \%$ & \\
p-value & 0.002 & \\
Penetration scale & & \\
Correlation & $44.9 \%$ & $-76.5 \%$ \\
p-value & 0.006 & $<0.001$ \\
\hline
\end{tabular}

Caption: DRAP = Dysphagia Risk Assessment Protocol

such as screenings or triage, which may be performed by other professionals, because no food is offered and the complaint is identified only for proper verification; clinical speech language assessment; and objective swallowing assessment (videofluoroscopy) $)^{(1,11-13)}$.

The work of Clavé et al. ${ }^{(14)}$ verified the effectiveness of the implementation of a screening test, changing the volume and viscosity (V-VST) associated to the videofluoroscopy, to identify the difficulty in swallowing by 97 subjects, 85 with dysphagia and 12 without dysphagia. They concluded this method is efficient enough to identify the difficulty in swallowing, although they stressed the need to perform the objective test to better understand the findings.

The clinical swallowing assessment is subject to the competence of the speech therapist to assess the anatomical structures and the neurophysiologic processes involved in swallowing ${ }^{(15)}$. During the assessment, it is important to obtain information on the anamnesis and on the specific procedures, which will allow the therapist to verify how the swallowing phases work; however, it is necessary to perform objective tests.

In some situations, clinical evaluation alone is not enough to accurately detect the presence of dysphagia, besides being little efficient to detect stasis in difficult places, which may lead to late aspiration ${ }^{(12)}$, thus making the use of objective evaluation methods necessary. A videofluoroscopy is the gold standard test that defines the anatomy and physiology of swallowing 
through different consistencies and, only from that, it is possible to confirm the presence of silent aspirations ${ }^{(1,2,12,13,16,17)}$.

Costa $^{(18)}$ stated that videofluoroscopy, besides being a necessary radiological method, provides an adequate diagnosis, allowing a specific therapeutic approach for the patients with dysphagia and that, without this test, the therapeutic approach occurs empirically.

In the study by Suzuki et al. ${ }^{(2)}$, researchers performed clinical and objective evaluation of 70 individuals with complaints of difficulties in swallowing, who have been divided into two groups, adults and elderly. A relation was observed between the complaints of sensation of food stuck in the esophagus and the presence of delayed esophageal emptying, by objective examination. In the elderly group, relations between the complaints of coughing and the present of stasis in piriform recesses and the complaint of coughing and the presence of laryngeal penetration through the contrast were found.

The authors also stressed the importance of performing a objective swallowing assessment even in cases which where there is no basis pathology in association to the swallowing complaint, because during the assessment, it was possible to identify specific characteristics in both the studied groups, which were not possible to be identified with clinical evaluation alone ${ }^{(2)}$.

Also, the same authors suggested that the method, when preceded by adequate clinical anamnesis, is able to conveniently characterize the degree of disorder and, often, to identify the cause of the anomaly with great precision.

From the analysis of the results of this study, it seems that obtaining only the history of the patient (reason for referral), the clinical and objective swallowing evaluation, in some cases, such as the presence of silent aspiration, is not enough for the correct diagnosis of dysphagia. Thus, initially an adequate clinical swallowing assessment is necessary, and must be complemented by objective tests.

Table 2 shows the correlation of clinical and objective assessments and the scale of penetration/aspiration. A correlation was observed between all the variables, given the highest of them between the results of videofluoroscopy and the penetration scale as $-76.5 \%$. The correlation was negative, because the adopted classifications were inverse, which is considered to be good.

Drozdz et al. ${ }^{(19)}$ analyzed the pharyngeal phase of swallowing of 15 patients with chronic coughing and compared the classification of swallowing based on the videofluoroscopy test and the penetration/aspiration scale developed by Rosenbek et al..$^{(9)}$. The authors observed a negative correlation between the degree of dysphagia and the presence of penetration and aspiration, evidencing that the greater the degree of dysphagia (lowest level of the scale by O'Neil et al. ${ }^{(8)}$ ), the greater the presence of penetration and aspiration (highest level in the scale by Rosenbek et al. $\left.{ }^{(9)}\right)$.

In the study by Sordi et al. ${ }^{(12)}$, researchers performed clinical and objective evaluations of 30 individuals diagnosed with neurological diseases. In 8 (26.66\%) cases, it was verified that the objective evaluation brought undetected information on clinical evaluation such as the presence of stasis, laryngeal penetration, and laryngotracheal aspiration, thus stressing the need to perform objective tests.

Xerez et al. ${ }^{(20)}$ studied the dynamics of swallowing in the subacute phase of strokes through clinical and objective assessments. From a total of 37 subjects, 26 (70.27\%) underwent both evaluations, and the presence of alteration in the oral phase, already evidenced in clinical evaluation, was confirmed; however, the findings of the pharyngeal phase in clinical assessment do not correlate with the objective assessment. Thus, authors highlighted the fact that it is not possible to confirm the presence of penetration/aspiration through clinical evaluation alone.

Furkim et al. ${ }^{(21)}$ correlated the findings of clinical and objective assessments of 32 children with cerebral palsy. They verified signs suggesting aspiration during the clinical assessment of 30 children in the sample, being confirmed in 27 through videofluoroscopy. In two cases, the clinical assessment did not show signs of aspiration and, after performing the objective test, its presence was confirmed. Given the findings, the authors emphasized that clinical and videofluoroscopy evaluations may be considered complementary in the research of aspiration occurrence, as there are cases in which aspiration is silent, being diagnosed only by videofluoroscopy.

A similar study evaluated the swallowing of 50 children with cerebral palsy, and from the clinical and objective assessments it was verified that all assessed patients had changes in their swallowing dynamics in both evaluations. It was concluded then that these evaluations are complementary and essential for the diagnosis of oropharyngeal dysphagias, being essential in defining the prognosis and determining therapeutic planning ${ }^{(22)}$.

In the case report by Bastilha et al. ${ }^{(23)}$, the authors compared the clinical and objective assessments in a patient with chronic obstructive pulmonary disease and pulmonary emphysema. In clinical exam, no signs suggesting laryngotracheal penetration and/or penetration were found, and the swallowing dynamics was considered normal. However, due to the complaint of chronic coughing by the patient, a videofluoroscopy was performed and a moderate oropharyngeal dysphagia with penetrations and silent aspiration was observed.

Gatto and Rehder ${ }^{(5)}$ performed clinical and videofluoroscopic evaluations in 20 subjects with stroke diagnosis, and it was verified that from the patients who denied choking with pasty consistency, $3(16.67 \%)$ had laryngeal penetration and $2(11.11 \%)$ had aspiration; from the ones who denied choking with liquids, $3(27.27 \%)$ had laryngeal penetration and 4 $(36.36 \%)$ had aspiration. The authors stressed that, even in cases where there are no specific complaints, patients must be carefully assessed and, in case of doubts on the clinical evaluation, they should be submitted to objective evaluation to avoid complications from silent aspirations.

Another study of 47 patients with oropharyngeal dysphagia and with neurological deficits concluded that, using videofluoroscopy as an evaluation method, it was possible to precisely classify the degree of dysphagia and, thus, provide a more specific approach in relation to the kind of food offered ${ }^{(24)}$.

Schelp et al. ${ }^{(25)}$ carried out a study with 102 patients, given that 41 of them took only the clinical swallowing assessment and 61 took the clinical and videofluoroscopy assessments. 
They found a higher incidence of dysphagia through the objective assessment (91\%) in comparison to the clinical assessment (76.5\%).

In a study carried out to verify the concordance between clinical and videofluoroscopic assessments, 50 men were evaluated, aged between 23 and 103 years, with complaints of difficulty in swallowing and different base pathologies. It was verified that the concordance between the evaluations was $72 \%$ for delay in oral transit, $62 \%$ for residues in the oral cavity, $66 \%$ for delay in pharyngeal transit, $42 \%$ for residue in the pharynx, and $76 \%$ for tracheal aspiration ${ }^{(26)}$.

The findings highlight that the assessments are complementary and, for the correct diagnosis of dysphagia, in some cases, the clinical speech language evaluations alone will not be enough.

\section{CONCLUSION}

From this work, it was evidenced that to diagnose the presence of dysphagia, it is not enough to obtain only the patient's historical data, without associating the results of the clinical evaluation using the standardized protocols, requiring often complementary exams such as videofluoroscopy for the correct identification of the alteration of swallowing. It was also possible to observe that the severity of dysphagia is correlated to the presence of penetration and aspiration, being important to combine the scale of severity of penetration/ aspiration for diagnosis.

*RM was responsible for the project and overall guidance of the execution and elaboration phases of the manuscript; BFTG, CCC, TCF, and DRCD were responsible for the outline of the study, the data analysis, and the elaboration of the manuscript; DFDB and SFS were responsible for the collection and tabulation of the data and the writing of the manuscript.

\section{REFERENCES}

1. Vale-Prodomo LP, Carrara-de-Angelis E, Barros APB. Avaliação clínica fonoaudiológica das disfagias. In: Jotz GP, Carrara-de-Angelis E, Barros APB. Tratado de deglutição e disfagia no adulto e na criança. Rio de Janeiro: Revinter; 2010. p. 61-7.

2. Suzuki HS, Nasi A, Ajzen S, Bilton T, Sanches EP. Avaliação clínica e videofluoroscópica de pacientes com distúrbios da deglutição - estudo comparativo em dois grupos etários: adultos e idosos. Arq Gastroenterol. 2006;43(3):201-5.

3. Barros AF, Fábio SR, Furkim AM. Correlação entre os achados clínicos da deglutição e os achados da tomografia computadorizada de crânio em pacientes com acidente vascular cerebral isquêmico na fase aguda da doença. Arq Neuropsiquiat. 2006;64(4):1009-14.

4. Lopes-Filho O, editor. Tratado de Fonoaudiologia. $2^{\mathrm{a}}$ edição. São Paulo: Tecmedd; 2005.

5. Gatto AM, Rehder MIBC. Comparação entre queixas de deglutição e achados videofluoroscópicos no paciente pós-acidente vascular encefálico. Rev CEFAC. 2006;8(3):320-7.
6. Padovani AR, Moraes DP, Mangili LD, Andrade CRF. Protocolo Fonoaudiológico de Avaliação do Risco para Disfagia (PARD). Rev Soc Bras Fonoaudiol. 2007;12(3):199-205.

7. Crary MA, Mann GD, Groher ME. Initial psychometric assessment of a functional oral intake scale for dysphagia in stroke patients. Arch Phys Med Rehab. 2005;86(8):1516-20.

8. O'Neil KH, Purdy M, Falk J, Gallo L. The dysphagia outcome and severity scale. Dysphagia. 1999;14(3):139-45.

9. Rosenbek J, Robbins JA, Roecker EB, Coyle J, Wood J. A penetrationaspiration scale. Dysphagia. 1996;11(2):93-8.

10. Furkim AM, Wolf AE. Avaliação clínica e instrumental da deglutição. In: Rehder MI, Branco A. Disfonia e disfagia: interface, atualização e prática clínica. Rio de Janeiro: Revinter; 2011. p. 39-49.

11. Martino R, Silver F, Teasell R, Bayley M, Nicholson G, Streiner DL, et al. The Toronto Bedside Swallowing Screening Test (TOR-BSST): development and validation of a dysphagia screening tool for patients with stroke. Stroke. 2009;40(2):555-61.

12. Sordi M, Mourão LF, Silva AA, Flosi LCL. Importância da interdisciplinaridade na avaliação das disfagias: avaliação clínica e videofluoroscópica da deglutição. Braz J Otorhinolaryngol. 2009;75(6):776-87.

13. Kellen PM, Becker DL, Reinhardt JM, Van Daele DJ. Computer-assisted assessment of hyoid bone motion from videofluoroscopic swallow studies. Dysphagia. 2010;25(4):298-306.

14. Clavé P, Arreola V, Romea M, Medina L, Palomera E, Serra-Prat M. Accuracy of the volume-viscosity swallow test for clinical screening of oropharyngeal dysphagia and aspiration. Clinical Nutrition. 2008;27:806-15.

15. Silva RG. Disfagia neurogênica em adultos: uma proposta para avaliação clínica. In: Furkim AM, Santini CS. Disfagias orofaríngeas. São Paulo: Pró-fono; 1999.

16. Costa MMB, Koch HA. Lateral laryngopharyngeal diverticulum: anatomical and videofluoroscopic study. Eur Radiol. 2005;15(7):1319-25.

17. Martin-Harris B, Brodsky MB, Michel Y, Castell DO, Schleicher M, Sandidge J, et al. MBS measurement tool for swallow impairment MBSImp: establishing a standard. Dysphagia. 2008;23(4):392-405.

18. Costa MMB. Videofluoroscopia: método radiológico indispensável para a prática médica. Radiol Bras. 2010;43(2):7-8.

19. Drozdz DRC, Costa CC, Jesus PRO, Trindade MS, Weiss G, Neto ABM, et al. Análise da fase faríngea da deglutição em portadores de tosse crônica. Int Arch Otorhinolaryngol. 2012;16(4):502-8.

20. Xerez DR, Carvalho YSV, Costa MMB. Estudo clínico e videofluoroscópico da disfagia na fase subaguda do acidente vascular encefálico. Radiol Bras. 2004;37(1):9-14.

21. Furkim AM, Behlau MS, Weckx LLM. Avaliação clinica e videofluoroscópica da deglutição em crianças com paralisia cerebral tetraparética espástica. Arq Neuropsiquiatr. 2003;61(3A):611-6.

22. Queiroz MAS, Andrade ISN, Haguette RCB, Haguette EF. Avaliação clínica e objetiva da deglutição em crianças com paralisia cerebral. Rev Soc Bras Fonoaudiol. 2011;16(2):210-4.

23. Bastilha GR, Mancopes R, Gonçalves BFT, Bilheri DFD. Resultados da avaliação clínica e objetiva da deglutição em paciente com tosse crônica: relato de caso. Int Arch Otorhinolaryngol. 2012;16(Suppl. 1):98.

24. Barbiera F, Condello S, de-Palo A, To Daro D, Mandracchia C, de Cicco D. Role of videofluorography swallow study in management of dysphagia in neurologically compromised patients. Radiol Med. 2006;111(6):818-27.

25. Schelp AO, Cola PC, Gatto AR, Silva RG, Carvalho LR. Incidência de disfagia orofaríngea após acidente vascular encefálico em hospital público de referência. Arq Neuropsiquiatr. 2004;62(2B):503-6.

26. Zenner PM, Losinski DS, Mills RH. Using cervical auscultation in the clinical dysphagia examination in long-term care. Dysphagia. 1995;10(1):27-31. 